Original paper

\title{
Salicylic acid-mediated salt stress tolerance by mitigation of the oxidative effects in Moringa
}

Fayza A. Faheed, Ahmed M. Hassanein, Abdullah El-nagish, Jehan Salem.

Botany and Microbiology Department, Faculty of Science, Sohag University, 82524 Sohag, Egypt.

doi:

\section{Abstract}

Salinity stress amelioration in Moringa was investigated on five weeks old plants by treatment with salicylic acid (SA) in a pot culture experiment. Salt stressed plants showed a reduction in growth and decreased carotenoid content, while ion leakage and lipid peroxidation increased significantly. To avoid oxidative stress due to salt stress, plants increased significantly the activities of studied antioxidant enzymes [superoxide dismutase (SOD), peroxidase (POX), catalase (CAT), and ascorbate peroxidase (APX)]. A significant increase in the activities of these enzymes was observed, resulted in amelioration of growth inhibition when stressed plants were subjected for exogenous application of SA. The role of esterases in support of antioxidant systems was discussed. Increase of SOD or POX activities under salt stress or SA treatment was not due to expression of new isoenzyme forms but because of overexpression of the turned on iso-loci. SA induced activation of the antioxidant system resulted in a significant increase of carotenoids content but $\mathrm{H} 2 \mathrm{O} 2$ concentration, lipid peroxidation and ions leakage significantly decreased. These results indicate that SA mediated increase plant content of ROS scavengers and membrane stability leading to promoting more stress tolerance in Moringa.

\section{KEYWORDS}

Salt stress,

Salicylic acid,

Izoenzymes,

ROS,

Stress markers,

Moringa.

CORRESPONDING AUTHOR

Abdullah El-nagish

ael.nagish@science.sohag.edu.eg

\section{INTRODUCTION}

Moringa (Moringa oleifera L.) is a fast grown tree belongs to the family Moringaceae. Tree leaves, fruits, flowers, immature pods and seeds are highly nutritious as human food or animal feeds. In addition, moringa is used as green manure to improve soil fertility (Davis, 2000). Also, Moringa is used as a food supplement and water treatment. The medical evidences of Moringa as nutritional, therapeutic, and prophylactic plant materials was reviewed (Fahey 2005).

Salinity is one of the environmental conditions which restrict the plant production, especially in arid and semi-arid regions. Under these conditions, few economical plant species such as
Moringa can be grown commercially (Qadir et al. 2014).

Physiological aspects such as seed germination, growth, photosynthesis and pigment content, carbohydrate and protein fractions, mineral composition and antioxidants are altered under salinity stress (Faheed et al., 2005; Shobbar et al. 2010; Faheed 2012; Jini \& Joseph 2017).

In plants, stress conditions produce and accumulate reactive oxygen species (ROS) leading to oxidative stress, they cause damage to cellular macromolecules including membranes, proteins and nucleic acids (Mittler 2002). Leakage of ions and peroxidation due to salt stress are two key indicators reflecting the degree of membrane 
injury (Yang et al. 2003; Tripathi et al. 2017). On the other side, stressed plants possess defense mechanisms by increasing the antioxidant systems to control the elevated concentrations of ROS. When the level of ROS exceeds the defense mechanisms, stressed plants will be adversely affected. It is carried out by increase of nonenzymatic antioxidant component such as carotenoids (Miyake \& Asada 1994; Ramel et al. 2012) and antioxidant enzymes such as superoxide dismutase (SOD; EC 1.15.1.1), peroxidase (POD; EC 1.11.1.7), catalase (CAT; EC 1.11.1.6) and ascorbate peroxidase (APX; EC 1.11.1.11) and others (Nakano \& Asada 1981; Hassanein 1999; Faheed 2012; Torabi et al. 2015; Sharma \& Laxmi 2015). Esterase such as feruloylesterases (EST; EC 3.1.1.73) catalyzes the release of ferulic acid from cell wall polysaccharides. Ferulic acid has higher potential of radical scavenging (Huang et al. 2013). Then, esterases mediates scavenging potential of ROS by liberate of ferulic acid from where is bonded. In addition, ferulic acid increased the expression of CAT, APX and POX, and protected the stressed plants by reducing toxic levels of H2O2 (Sharma \& Laxmi 2015). Various agents such as jasmonic acid, ferulic acid and salicylic acid mediate the acclimation of plants to environmental stress (Senaratna et al. 2000; Faheed 2012; Huang et al. 2013; Jini \& Joseph 2017).

Exogenous application of SA increased membrane stability by decreasing malondialdehyde content (MDA) (Kazemi et al. 2011; Faheed 2012). In addition, SA was found to support the antioxidant scavengers in plants such as SOD, POX, CAT, APX and esterases (Horvath et al. 2007; Hayat et al. 2010; Liu et al. 2014; Abdul Qados 2015; Ma et al. 2017).

Exogenous application of SA results in increase of compatible osmotic solutes and/or activities of antioxidant enzymes (Pirasteh-Anosheh et al. 2014; Faheed 2012; Abdul Qados 2015; Ma et al. 2017). Except moringa plant, application of SA to improve growth under stress conditions was examined in different plant species (Javaheri et al. 2012; Bagheri 2014), but further studies using different plant species and stress conditions are needed to describe how SA mediates the recovery of plants from salinity damage. Consequently, the aim of this work was to investigate how salicylic acid mediates increase of ROS scavengers and membrane stability to mitigate the injuries of salt stress in Moringa.

\section{MATERIALS AND METHODS}

\section{Growth conditions}

In this work, Moringa seeds were obtained from CASP "Central Administration for Seed Production, 8 Gamaa El Kahira St, Giza, Egypt". Seeds were surface sterilized and divided into two groups. One half of these Moringa seeds were soaked for $5 \mathrm{~h}$ in $0.5 \mathrm{mM} \mathrm{SA}$, while the other half of seeds was soaked for the same time in deionized water (control). For seed germination and plant growth, ten Moringa seeds were sown in plastic pots. Three weeks old plants were sprayed with or without $0.5 \mathrm{mM} \mathrm{SA}$. Plants were harvested after further two weeks and subjected to the intended analysis. Plants were germinated and grow using plastic pots supplemented with 1700 gm air-dried soil. The field capacity of the used soil was determined (24.45\%). Consequently, soil in pots was daily adjusted to full field capacity using one tenth strength of Hoagland's solution (Hewitt 1963).

\section{Determination of some growth parameters}

Growth parameters including length, fresh weight (FW) and dry weight (DW) were determined/ seedling. Determination of DW was estimated after drying the plant material to constant weight at $65^{\circ} \mathrm{C}$ for $48 \mathrm{~h}$ in drying oven. Then, fresh weight and dry weight of the same sample was used to estimate water content.

\section{Determination of carotenoids}

Carotenoids of moringa plants subjected to different concentrations of $\mathrm{NaCl}$ with or without SA treatments were measured in fresh leaf samples, a week before the harvest time. Moringa leaf samples $(0.250 \mathrm{~g})$ were homogenized in acetone $(85 \% \mathrm{v} / \mathrm{v})$. Carotenoids were calculated according to Lichtenthaler (1987). 


\section{Determination of membrane permeability}

Membrane permeability of the excised leaves of Moringa plants was estimated according to Yan et al. (1996). Briefly, parts from the middle of the leaves $(0.5 \mathrm{gm})$ were cut, transferred into glass beaker containing $10 \mathrm{ml}$ of deionized water and incubated at $30^{\circ} \mathrm{C}$ for $20 \mathrm{~h}$ in the dark with shaking. Using a conductivity meter (Mi 170 Bench Meter EC/ TDS/ NaCl/ Temp.), the electrolyte leakage (EC) was measured. After boiling for $2 \mathrm{~min}$, samples conductivities were measured again and percentages of EC was calculated $(\% \mathrm{EC}=\mathrm{EC} 1 / \mathrm{EC} 2 \times 100, \mathrm{EC} 1$ and $\mathrm{EC} 2$ are the measured electrolyte conductivities before and after boiling, respectively).

\section{Determination of malondialdehyde}

In terms of malondialdehyde (MDA) content, the level of lipid peroxidation was determined under the applied experimental conditions (Hernandez and Almansa 2002). Plant leaf (1000 mg) was homogenized in $5 \mathrm{ml}$ of $5 \%$ trichloroacetic acid (TCA) under chill conditions; the obtained homogenate was centrifuged at $15000 \mathrm{~g}$ for 20 min at $4 \mathrm{oC}$. Mixture of $1 \mathrm{~mL}$ supernatant, $3 \mathrm{~mL}$ of $0.5 \%$ thiobarbituric acid (TBA) and $20 \%$ TCA was prepared and heated at $95^{\circ} \mathrm{C}$ for $30 \mathrm{~min}$. Then, mixture was quickly cooled on ice. The mixture was centrifuged at $10,000 \mathrm{~g}$ for $10 \mathrm{~min}$ and transferred to measure its absorbance at $532 \mathrm{~nm}$. Non-specific absorption at $600 \mathrm{~nm}$ was subtracted. Finally, MDA equivalent was calculated (Zhang, 1992): MDA $(\mu \mathrm{mol} / \mathrm{g} \mathrm{FW})=((\mathrm{A} 532-\mathrm{A} 600) / 155)$ $\times 103)$.

\section{Protein extraction}

For determination of enzyme activity under the applied conditions, Moringa leaf tissue $(0.5 \mathrm{gm})$ was homogenized in a mixture of $3 \mathrm{ml}$ of $50 \mathrm{mM}$ potassium phosphate buffer ( $\mathrm{pH} 7$ ), $0.1 \mathrm{mM}$ EDTA and $1 \%$ polyvinylpolypyrrolidone.

The homogenate was centrifuged at $15000 \mathrm{~g}$ for $15 \mathrm{~min}$ and the obtained supernatant was stored at $-20{ }^{\circ} \mathrm{C}$. All protein extraction steps were carried out at $4{ }^{\circ} \mathrm{C}$. Enzyme activities were estimated using Appota $1600 \mathrm{UV} / \mathrm{Vis}$ spectrophotometer (Nakano \& Asada 1981).

\section{Determination of superoxide dismutase}

Protein extract of plants grown under the applied conditions was used to determine superoxide dismutase (EC. 1.15.1.1) activity according to Beauchamp and Fridovich (1971). In this concern, mixture of $3 \mathrm{ml}$ containing $50 \mathrm{mM}$ phosphate buffer ( $\mathrm{pH}$ 7.8), $9.9 \mathrm{mM}$ L-methionine, $57 \mathrm{mM}$ nitrobluetetrazolium (NBT), and $0.0044 \%(\mathrm{w} / \mathrm{v})$ riboflavin were used. The photoreduction of NBT resulted in the formation of purple formazan and it was measured at $560 \mathrm{~nm}$. Activity of SOD was expressed as the amount of SOD that inhibits the nitrobluetetrazolium photoreduction (Extinction factor $\left.(E)=10.3 \mathrm{mM} \mathrm{cm}^{-1}\right)$. Then, enzyme activity was expressed as $\mathrm{mM}$ of NBT that reduced $\mathrm{min}^{-1}$ $\mathrm{g}^{-1} \mathrm{FW}$.

\section{Determination of peroxidase activity}

Peroxidase (POX-EC 1.11.1.7) activity was estimated in $50 \mu \mathrm{L}$ of the prepared enzyme extract using $3 \mathrm{~mL}$ of reaction mixture. It contains $40 \mathrm{mM}$ phosphate buffer (pH 6.5), $0.1 \mathrm{mM}$ EDTA, $25 \mathrm{mM}$ guaiacol and $15 \mathrm{mM} \mathrm{H}_{2} \mathrm{O}_{2}$. Oxidation of guaiacol $(\mathrm{E}=26.6 \mathrm{mM} \mathrm{cm}-1)$ was measured at $470 \mathrm{~nm}$. The enzyme activity was estimated in terms of $\mu \mathrm{mol}$ of guaiacol that oxidized $\min ^{-1} \mathrm{~g}^{-1} \mathrm{FW}$ at 25 $\pm 2{ }^{\circ} \mathrm{C}$ (Zhang 1992; MacAdam et al. 1992).

\section{Determination of catalase activity}

Catalase (CAT- EC 1.11.1.6) activity was estimated depending on previously described protocol of Aebi (1984). The reaction mixture (3 $\mathrm{mL}$ ) was prepared to contain $50 \mathrm{mM}$ phosphate buffer ( $\mathrm{pH}$ 7.0), $0.1 \mu \mathrm{M}$ EDTA, $25 \mathrm{mM} \mathrm{H}_{2} \mathrm{O}_{2}$ and $50 \mu \mathrm{L}$ enzyme extract. The decrease in the concentration of $\mathrm{H}_{2} \mathrm{O}_{2}$ was measured at $240 \mathrm{~nm}$ and quantified by its molar extinction coefficient $\left(36 \mathrm{M}^{-1} \mathrm{~cm}^{-1}\right)$. Results were expressed as $\mu \mathrm{mol}$ $\mathrm{H}_{2} \mathrm{O}_{2} \min ^{-1} \mathrm{~g}^{-1} \mathrm{FW}$.

\section{Determination of ascorbate peroxidase activity}

Ascorbate (APX-EC 1.11.1.11) activity was investigated by estimating the rate of ascorbate oxidation (extinction coefficient: $2.8 \mathrm{~mm}^{-1} \mathrm{~cm}^{-1}$ ). Reaction mixture $(3 \mathrm{ml})$ containing $50 \mathrm{~mm}$ 
phosphate buffer ( $\mathrm{pH} 7.0), 15 \mathrm{mM} \mathrm{H} 2 \mathrm{O} 2,0.1 \mathrm{~mm}$ EDTA, $0.5 \mathrm{~mm}$ sodium ascorbate, and $50 \mu \mathrm{l}$ enzyme extract was prepared. The enzyme activity was expressed as $\mathrm{mM}$ of ascorbate oxidized $\mathrm{mim}^{-1}$ $\mathrm{g}^{-1} \mathrm{FW}$ at $25 \pm 2{ }^{\circ} \mathrm{C}$.

\section{Detection of isoenzyme patterns}

Three isoenzymes (SOD, POX and EST) were visualized to study their expression under salinity stress with or without SA treatments using previously prepared protein extract. Slab gels (7.5 $\%$ polyacrylamide) were loaded by protein samples and electrophoretic runs were carried out at $24 \mathrm{~mA}$ for $6 \mathrm{~h}$ at $10{ }^{\circ} \mathrm{C}$. Run buffer containing $0.025 \mathrm{M}$ Tris and $0.129 \mathrm{M}$ glycine buffer $\mathrm{pH} 8.9$ was used. Bands of SOD, POX and EST were visualized according to the methods of Beauchamp \& Fridovich (1971), Siegel \& Galston (1967) and Brewer (1970), respectively.

\section{Statistical analysis}

In this work, all experiments were designed as completely randomized with three replications. The obtained data were statistically analyzed by ANOVA.

\section{RESULTS}

Germination percentage, plant height, fresh and dry weights and water content of moringa plants decreased significantly upon exposure to salt stress especially at relatively high salinity levels compared to control plants (Table 1). Reduction in the previous determined parameters was significantly improved when moringa plants were treated by $0.5 \mathrm{mM} \mathrm{SA}$, especially at high salinity levels.

The carotenoids content of stressed moringa plants showed a highly significant decrease under all salinity levels (Table 2). Treatment of the salt stressed moringa plants with SA resulted in insignificant decrease in the carotenoids content at relatively low $\mathrm{NaCl}$ concentration $(50 \mathrm{mM} \mathrm{NaCl})$. On the other hand, exogenous application of SA caused a highly significant increase $(\mathrm{P}<0.01)$ in the carotenoids content when the concentration of $\mathrm{NaCl}$ was increased more than $50 \mathrm{mM}$ (100 to 200 $\mathrm{mM})$.

The changes in stress markers such as membrane permeability, lipid peroxidation as well as concentration of $\mathrm{H} 2 \mathrm{O} 2$ of moringa plants were studied (Fig. 1a). A significant increase in membrane permeability of excised moringa leaves was observed when the concentration of $\mathrm{NaCl}$ was increased more than $50 \mathrm{mM}$. Exogenous application of SA showed a significant decrease (P $<0.05$ ) in membrane permeability.

It is well known that MDA is the key product of membrane-lipid peroxidation. The values of MDA in Moringa plants showed highly significant increase at moderate and high salinity levels compared to control plants. Exogenous application of SA alleviated significantly the drastic increase in MDA values $(\mathrm{P}<0.05)$ as compared with the corresponding salinized level (Fig. 1b).

Concentration of $\mathrm{H}_{2} \mathrm{O}_{2}$ showed highly significant increase in shoots of moringa plants under the influence of moderate and high levels of salinity.

Under these conditions, SA-treated plants showed a highly significant decrease $(\mathrm{P}<0.01)$ in $\mathrm{H}_{2} \mathrm{O}_{2}$ concentration compared to SA untreated-stressed plants (Fig. 1c).

The activity of SOD, POX and APX increased with the increase in $\mathrm{NaCl}$ concentration (Fig. 2). On the other side, CAT activity showed a general decrease at salinity stress treatments except at 100 $\mathrm{mM} \mathrm{NaCl}$, where a significant increase in CAT activity was detected compared to that of control plants. In comparison with stressed- SA- untreated plants, exogenous application of SA resulted in significant increase $(\mathrm{P}<0.05)$ in $\mathrm{SOD}, \mathrm{POX}, \mathrm{CAT}$ and APX activities. 
Table (1) Effect of different concentrations of $\mathrm{NaCl}(0,50,100,150,200,250 \mathrm{mM})$ on growth parameters of Moringa plants treated with or without $0.5 \mathrm{mM} \mathrm{SA}$.

\begin{tabular}{|c|c|c|c|c|c|c|c|c|c|c|}
\hline & $\begin{array}{l}\mathrm{NaCl} \\
(\mathrm{mM})\end{array}$ & $\begin{array}{c}\text { Germination } \\
(\%)\end{array}$ & $\begin{array}{l}\text { Shoot length } \\
\text { (cm) }\end{array}$ & $\begin{array}{c}\text { Root Length } \\
\text { (cm) }\end{array}$ & $\begin{array}{c}\text { Fresh Weight } \\
\text { of Shoot } \\
\left(\text { g plant }^{-1}\right)\end{array}$ & $\begin{array}{l}\text { Dry Weight } \\
\text { of Shoot (g } \\
\left.\text { plant }^{-1}\right)\end{array}$ & $\begin{array}{c}\text { Water } \\
\text { content } \\
\text { /Shoot } \\
(\%)\end{array}$ & $\begin{array}{c}\text { Fresh } \\
\text { Weight of } \\
\text { Root } \\
\left(\text { g plant }^{-1}\right)\end{array}$ & $\begin{array}{c}\text { Dry Weight } \\
\text { of Root } \\
\left.\text { (g plant }^{-1}\right)\end{array}$ & $\begin{array}{c}\text { Water } \\
\text { content } \\
/ \text { Root } \\
(\%)\end{array}$ \\
\hline \multirow{6}{*}{$\stackrel{0}{\underset{I}{I}}$} & $\begin{array}{c}\text { Control } \\
(0.0)\end{array}$ & 94.44 & $18.30 \pm 1.01$ & $10.40 \pm 1.39$ & $1.64 \pm 0.09$ & $0.54 \pm 0.07$ & 67.07 & $0.51 \pm 0.03$ & $0.136 \pm 0.03$ & 73.55 \\
\hline & 50 & 92.22 & $16.20 \pm 0.65 * *$ & $9.33 \pm 1.70$ & $1.51 \pm 0.08 *$ & $0.40 \pm 0.03 *$ & 73.11 & $0.45 \pm 0.04$ & $0.14 \pm 0.026$ & 69.34 \\
\hline & 100 & 76.66 & $14.03 \pm 0.20 * *$ & $8.43 \pm 0.51 *$ & $1.39 \pm 0.07 * *$ & $0.31 \pm 0.02 * *$ & 77.75 & $0.34 \pm 0.04 * *$ & $0.097 \pm 0.01 *$ & 71.83 \\
\hline & 150 & 64.44 & $10.10 \pm 0.55 * *$ & $8.80 \pm 0.91 *$ & $0.96 \pm 0.03 * *$ & $0.27 \pm 0.04 * *$ & 71.18 & $0.28 \pm 0.04 * *$ & $0.095 \pm 0.005^{*}$ & 66.63 \\
\hline & 200 & 46.44 & $8.70 \pm 0.72 * *$ & $5.73 \pm 0.64 * *$ & $0.69 \pm 0.04 * *$ & $0.26 \pm 0.06 * *$ & 62.68 & $0.23 \pm 0.04 * *$ & $0.076 \pm 0.011 * *$ & 66.96 \\
\hline & 250 & 36.66 & $6.23 \pm 0.70 * *$ & $3.33 \pm 0.90 * *$ & $0.55 \pm 0.07 * *$ & $0.19 \pm 0.02 * *$ & 64.36 & $0.14 \pm 0.03 * *$ & $0.054 \pm 0.009 * *$ & 63.41 \\
\hline \multirow{6}{*}{ 隹 } & 0.0 & 92.22 & $17.80 \pm 0.36$ & $11.06 \pm 0.96$ & $1.63 \pm 0.05$ & $0.52 \pm 0.09$ & 68.16 & $0.52 \pm 0.03$ & $0.131 \pm 0.043$ & 74.68 \\
\hline & 50 & 90 & $15.73 \pm 0.77 * *$ & $11.63 \pm 1.15$ & $1.54 \pm 0.06$ & $0.49 \pm 0.04$ & 67.97 & $0.46 \pm 0.04$ & $0.110 \pm 0.019$ & 76.36 \\
\hline & 100 & 66.67 & $14.33 \pm 0.80 * *$ & $9.10 \pm 1.24 *$ & $1.40 \pm 0.03 * *$ & $0.30 \pm 0.09 * *$ & 78.20 & $0.4 \pm 0.07 * *$ & $0.101 \pm 0.016^{*}$ & 74.75 \\
\hline & 150 & 58.88 & $10.86 \pm 0.35 * *$ & $6.73 \pm 0.23 * *$ & $1.16 \pm 0.10 * *$ & $0.29 \pm 0.07 * *$ & 75.07 & $0.30 \pm 0.02 * *$ & $0.092 \pm 0.007 *$ & 69.73 \\
\hline & 200 & 41.11 & $9.16 \pm 0.60 * *$ & $5.56 \pm 0.70 * *$ & $0.92 \pm 0.05 * *$ & $0.27 \pm 0.04 * *$ & 70.04 & $0.27 \pm 0.03 * *$ & $0.096 \pm 0.014 *$ & 65.06 \\
\hline & 250 & 31.11 & $7.73 \pm 0.86 * *$ & $5.50 \pm 0.91 * *$ & $0.68 \pm 0.06^{* *}$ & $0.23 \pm 0.02 * *$ & 66.18 & $0.24 \pm 0.03^{* *}$ & $0.073 \pm 0.01 * *$ & 70.41 \\
\hline \multicolumn{3}{|c|}{ LSD at $5 \%$} & 0.86 & 1.30 & 0.05 & 0.038 & - & 0.031 & 0.006 & - \\
\hline \multicolumn{3}{|c|}{ LSD at $1 \%$} & 1.12 & 1.94 & 0.14 & 0.19 & - & 0.12 & 0.009 & - \\
\hline
\end{tabular}

Table (2) Effect of different concentrations of $\mathrm{NaCl}(0,50,100,150,200,250 \mathrm{mM})$ on carotenoids content of moringa plants treated with or without $0.5 \mathrm{mM} \mathrm{SA}$

\begin{tabular}{|c|c|c|}
\hline \multirow{4}{*}{$\begin{array}{c}\text { NaCl conc. } \\
(\mathrm{mM})\end{array}$} & $\begin{array}{c}\text { Carotenoid } \\
(\mathrm{mg} / \mathrm{g} \mathrm{FW})\end{array}$ \\
\hline \multirow{4}{*}{$*$} & 0 & $0.38 \pm 0.011$ \\
\cline { 2 - 3 } & 50 & $0.32 \pm 0.003^{* *}$ \\
\cline { 2 - 3 } & 100 & $0.29 \pm 0.008^{* *}$ \\
\cline { 2 - 3 } & 150 & $0.19 \pm 0.011^{* *}$ \\
\hline \multirow{4}{*}{$\approx$} & 200 & $0.17 \pm 0.013^{* *}$ \\
\cline { 2 - 3 } & 250 & $0.11 \pm 0.006^{* *}$ \\
\cline { 2 - 3 } & 0 & $0.37 \pm 0.004$ \\
\cline { 2 - 3 } & 50 & $0.34 \pm 0.004$ \\
\cline { 2 - 3 } & 100 & $0.33 \pm 0.008^{* *}$ \\
\hline & 200 & $0.24 \pm 0.011^{* *}$ \\
\hline \multicolumn{2}{|c|}{ LSD at 5\% } & $0.19 \pm 0.009 * *$ \\
\hline \multicolumn{2}{|c|}{ LSD at $1 \%$} & $0.13 \pm 0.010^{* *}$ \\
\hline
\end{tabular}

Values are means of three replicates \pm standard deviation (SD)

Statistical significance of differences compared to control: *significant at $\mathrm{P}<0.05$; ** significant at $\mathrm{P}<0.01$

Under the applied conditions, SOD of salt stressed Moringa plants treated with or without SA was visualized (Fig. 3). Both SA treated or untreated plants expressed five isoenzyme forms (SOD-1, SOD-2, SOD-3, SOD-4 and SOD-5). Plants subjected to moderate or relatively high $\mathrm{NaCl}$ concentrations $(150,200$ and $250 \mathrm{mM} \mathrm{NaCl}$ ) expressed isoenzyme form SOD-6. The staining intensity of isoenzyme form SOD-1, SOD-2 and SOD-4 increased with the increase of $\mathrm{NaCl}$ concentrations. Comparison between SOD patterns of SA treated plants with SA untreated plants indicated that untreated-stressed plants showed slightly low staining intensity. 

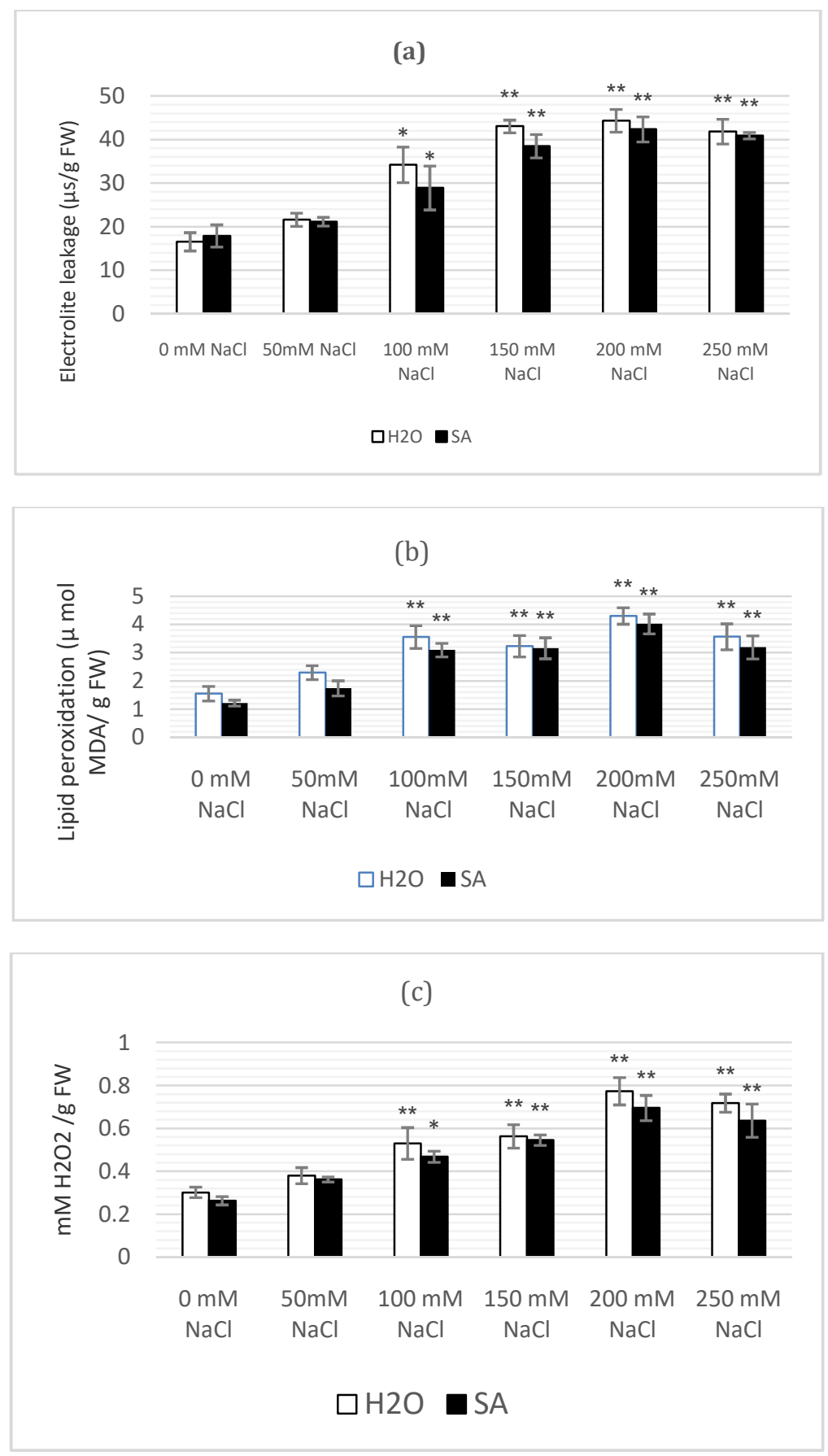

Fig. (1) Effect of $(0,50,100,150,200,250) \mathrm{mM} \mathrm{NaCl}$, on (a) electrolyte leakage, (b) lipid peroxidation, (c) hydrogen peroxide production of the shoots of Moringa plants treated with or without $0.5 \mathrm{mM} \mathrm{SA}$.

Moringa shoots expressed nine different peroxidase isoenzyme forms (Fig. 4). Generally, staining intensity of all POX isoenzyme forms increased with the increase of $\mathrm{NaCl}$ concentrations with or without SA treatments. Comparing between peroxidase patterns of SA untreated (lanes 1-6) plants with treated plants (lanes 7-12) indicated that SA treated plants expressed slight increase in staining intensity of POX isozyme forms.

A total of ten different EST isoenzyme forms were detected (Fig. 5). SA untreated plants expressed isoenzyme form EST-4 at salinity levels of 150 and $200 \mathrm{mM} \mathrm{NaCl}$, while the same isoenzyme form was detected in SA treated plants subjected to $100,150,200$ and $250 \mathrm{mM} \mathrm{NaCl}$ levels. 


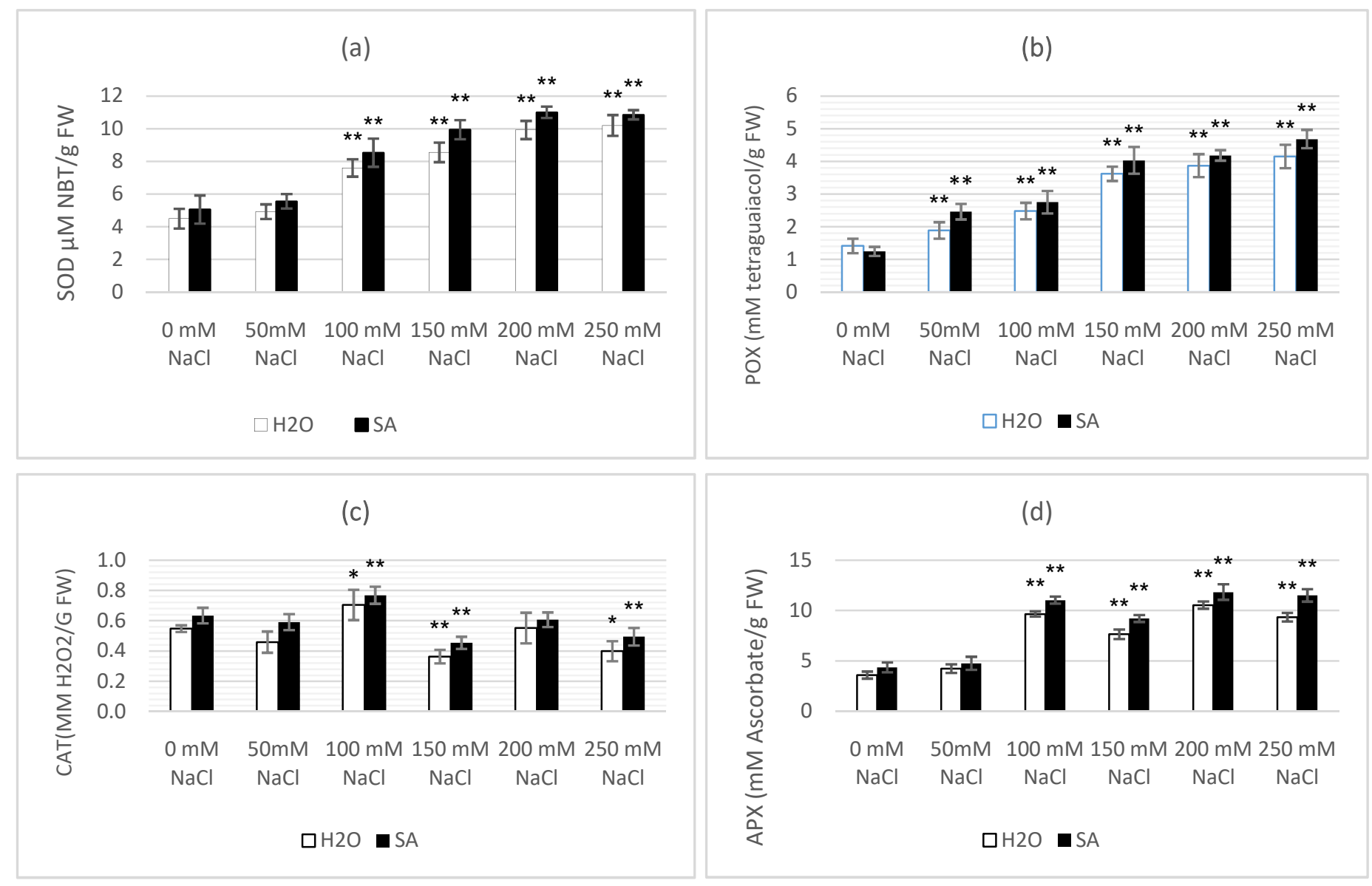

Figure (2) Effect of $(0,50,100,150,200,250) \mathrm{mM} \mathrm{NaCl}$, on activity of (a) SOD, (b) POX, (c) CAT, (d) APX of the shoots of moringa plants treated with or without $0.5 \mathrm{mM} \mathrm{SA}$.

Values are means of three replicates \pm standard deviation (SD)

Statistical significance of differences compared to SA untreated plants: *significant at $\mathrm{P}<0.05 ; * *$ significant at $\mathrm{P}<0.01$.

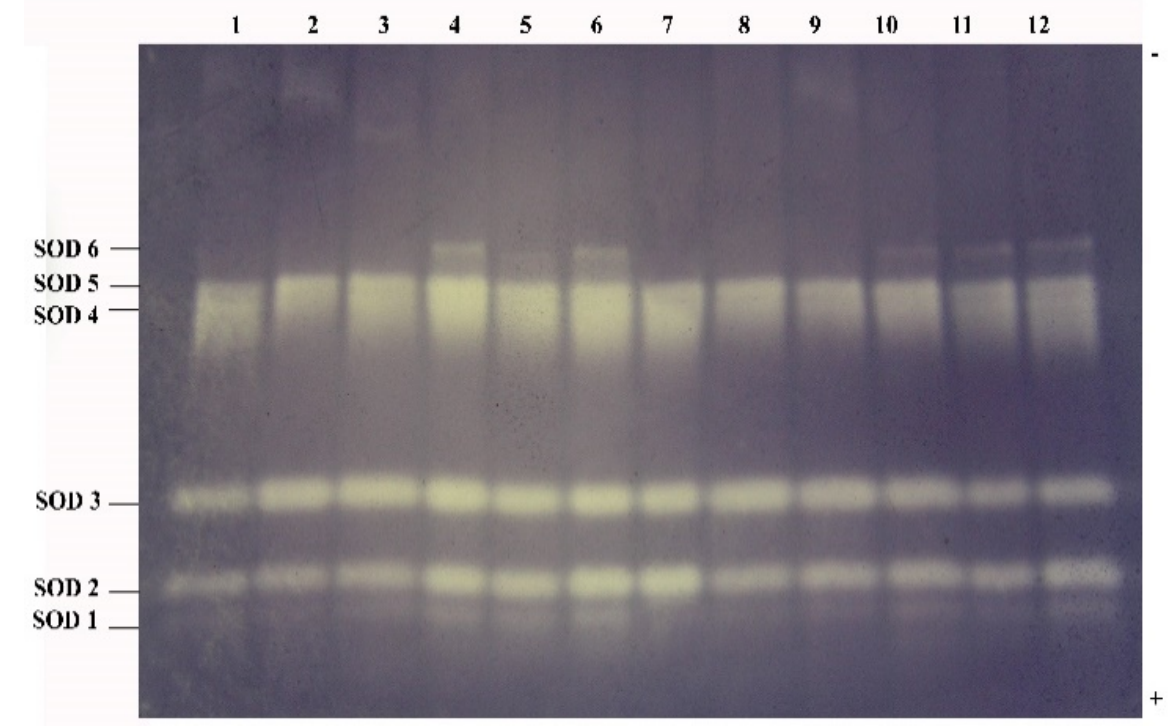

Figure (3) Native gel electrophoresis of SOD isoenzyme pattern of moringa shoots grown for five weeks in soil under salinity stress, SA treated plants (lanes 1 to 6), SA untreated plants (lanes 7 to 12); 0 (lanes 1, 7), 50 (lanes 2, 8), 100 (lanes 3, 9), 150 (lanes 4, 10), 200 (lanes 5, 11), 250 (lanes 6, 12) mM NaCl respectively. 


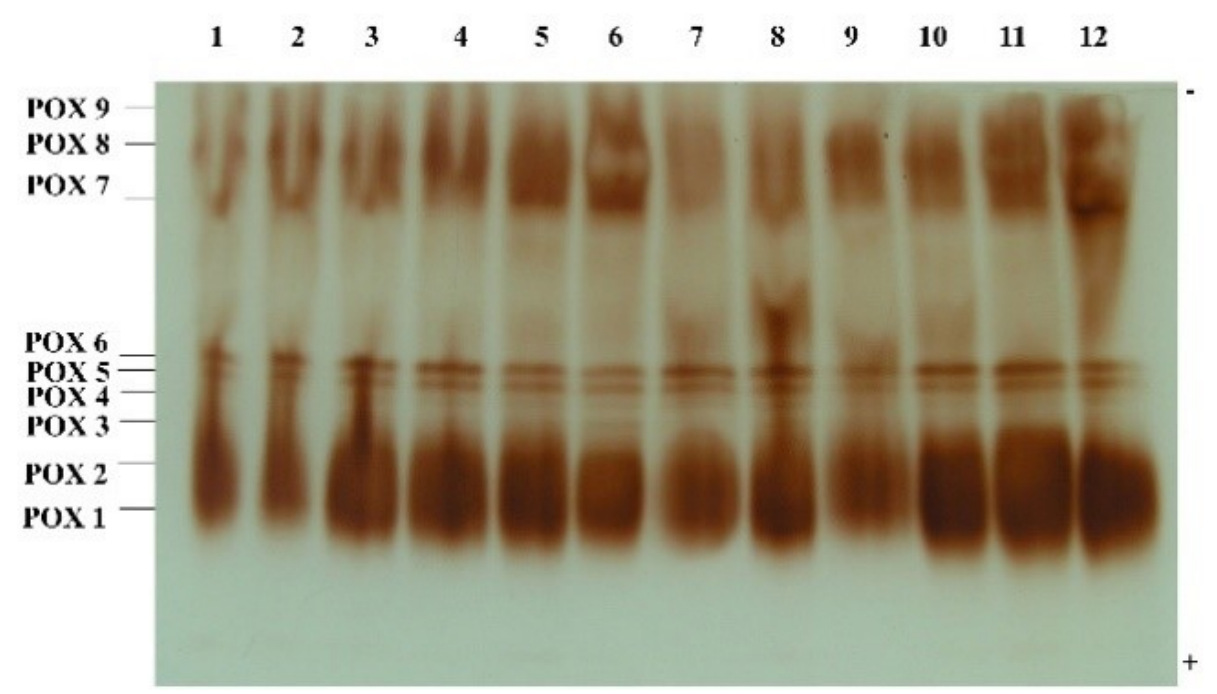

Figure (4) Native gel electrophoresis of POX isoenzyme pattern of moringa shoots grown for five weeks in soil under salinity stress, SA untreated plants (lanes 1 to 6), SA treated plants (lanes 7 to 12); 0 (lanes 1, 7), 50 (lanes 2, 8), 100 (lanes 3, 9), 150 (lanes 4, 10), 200 (lanes 5, 11), 250 (lanes 6, 12) mM NaCl respectively.

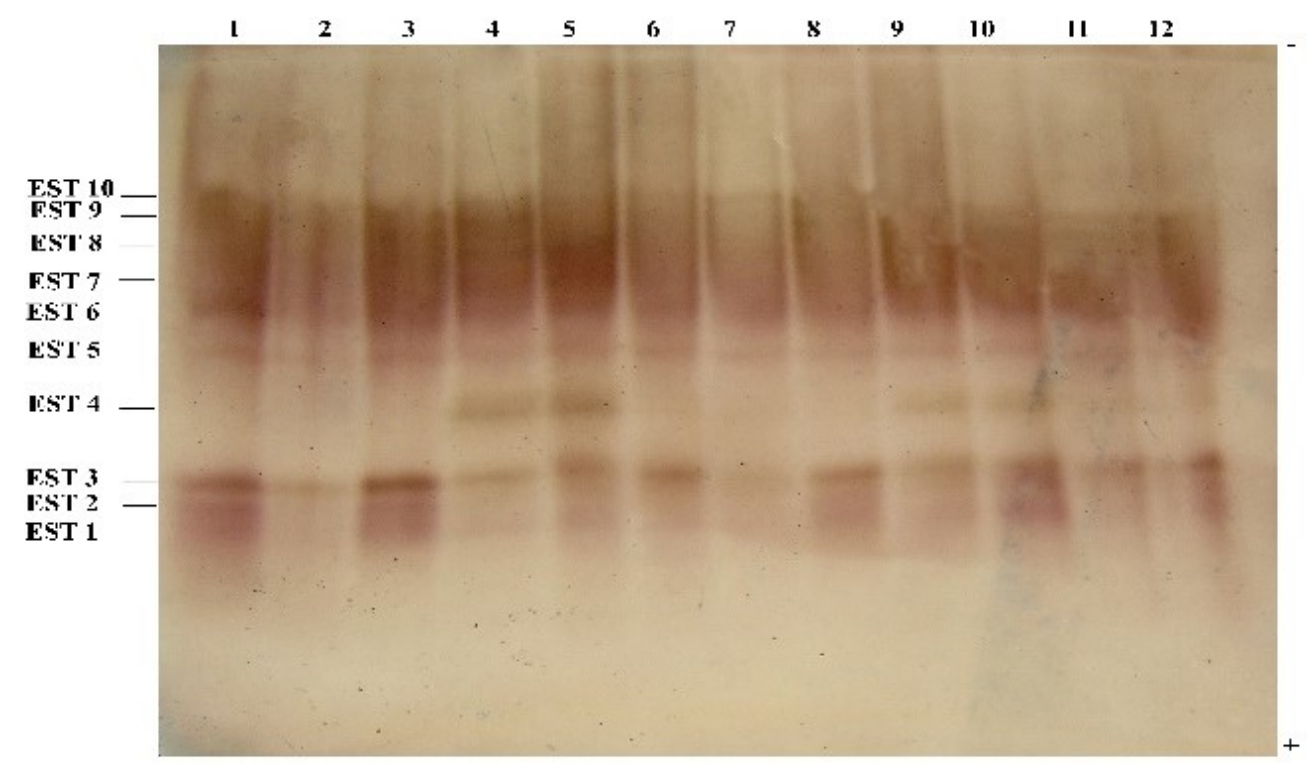

Figure (5) Native gel electrophoresis of EST isoenzyme pattern of moringa shoots grown for five weeks in soil under salinity stress, SA untreated plants (lanes 1 to 6), SA treated plants (lanes 7 to 12); 0 (lanes 1, 7), 50 (lanes 2, 8), 100 (lanes 3, 9), 150 (lanes 4, 10), 200 (lanes 5, 11), 250 (lanes 6, 12) mM NaCl respectively.

\section{DISCUSSION}

The obtained results showed that salt stress decreased seed germination and plant growth in Moringa. This reduction may be explained as an adaptive response of Moringa to salt stress (Acosta-Motos et al. 2015). The reduction in growth was significantly improved upon treatment of Moringa plants with $0.5 \mathrm{mM}$ SA. In our work, Moringa plants were raised from the seeds presoaked in SA, it was potentially alleviate the toxic effects which were generated by $\mathrm{NaCl}$ leading to expression of effective tolerance against salinity. Exogenous application of SA increased some physiological concepts; thereby SA improved growth of salt stressed Moringa plants and other plant species (El-Tayeb 2005).

Stress tolerance is positively correlated with increase the efficiency of antioxidative systems including enzymatic and non-enzymatic 
components. Carotenoids are effective nonenzymatic antioxidant component which are able to share with other components to scavenge ROS (Miyake \& Asada 1994; Ramel et al. 2012), but they showed a highly significant decrease under salinity stress in Moringa. This situation could be significantly reversed when Moringa plants were treated with SA.

Diverse abiotic stresses adversely affect the integrity and functions of plasma membrane. Membrane disruptions take place in plants subjected to salinity stress and its degree is measured by the levels of electrolyte leakage (Hayat et al. 2012, Barkla \& Vera-Estrella 2015; Guo et al. 2019). In this work, electrolyte leakages increased significantly under moderate and relatively high $\mathrm{NaCl}$ concentrations up to 250 $\mathrm{mM}$. Membrane damage by salt stress induced accumulation of ROS leading to oxidative damage. ROS species can activate either GORK (guard cell outward-rectifying $\mathrm{K}$ ) or NSCC (nonselective cation channels) channels to enhance poatssium leakage leading to cell death under salt stress (Chakraborty et al. 2016; Wu et al. 2018). So, prevention of $\mathrm{K}$ leakage via ROS-activated NSCC under salt stress is an essential prerequisite for salt tolerance in plants. Application of SA can control K loss via ROS activated NSCC in salt stressed plants (Demidchik et al. 2010; Poór et al. 2011b). In addition, adversity effects of salinity were moderately ameliorated by the exogenous application of SA as was reported by (Zhang et al. 2014).

The obtained data indicated that increase the concentrations of $\mathrm{NaCl}$ levels induce extensive lipid peroxidation in moringa plant. Level of lipid peroxidation, was measured as malondialdehyde (MDA) content and it increased under salinity stress which may be due to the oxidative damage of the organelle membranes. Exogenous SA improved the growth parameters of moringa plant under salt stress by promoting more stress tolerance through the enhancement of photosynthetic pigments and maintaining membrane integrity as was reported (El-Tayeb 2005; Gunes et al. 2007).
Moringa plants under salt stress showed highly significant increase in $\mathrm{H}_{2} \mathrm{O}_{2}$ at moderate and high levels of salinity, it was significantly reduced by SA treatment; thereby it resulted in additional tolerance against oxidative stress generated by $\mathrm{NaCl}$ (Panda \& Patra 2007). Both SA and $\mathrm{H}_{2} \mathrm{O}_{2}$ at low concentrations are signaling molecules, resulting in additional stress tolerance against biotic and abiotic stresses (Love et al. 2008; Quan et al. 2008). Obtained data indicated that exogenous application of SA decreased the concentration of $\mathrm{H}_{2} \mathrm{O}_{2}$ of salt-stressed Moringa plants.

When plants are subjected to environmental stresses, ROS are often elevated leading to disruption of the plant cell metabolism and reduction in plant growth. In Moringa, the activities of a variety of antioxidant enzymes such as SOD, POD, CAT and APX were increased to control ROS damage. These enzymes reduce the elevated concentration of $\mathrm{H}_{2} \mathrm{O}_{2}$, prevent lipid peroxidation and decrease leakage of important nutrients such as $\mathrm{K}$ (data not shown). Further increase of these enzymes was detected when stressed plants were treated with SA. Increase the activities of antioxidant enzymes in salt stressed moringa plants due to SA was confirmed in other plant species (Knorzer et al. 1999; Zhang et al. 2014).

In this work, two of the studied antioxidant enzymes were stained to detect any variation in the expression of iso-loci of these enzymes. Both SA treated and untreated moringa plants expressed five isoenzyme forms of peroxidases but the sixth one (SOD-6) was detected only under moderate or relatively high $\mathrm{NaCl}$ concentrations $(150,200$ and $250 \mathrm{mM} \mathrm{NaCl}$ ). Generally, staining intensity of SOD or POX isoezyme forms increased with the increase of $\mathrm{NaCl}$ concentrations, further slight increase in staining intensities of some bands of SOD (SOD-2 and ) and POX (POX-1, 2, 5, 6, 7, 8) was detected when salinized plants were treated with SA. The results obtained from determination of enzyme activity (Fig. 2 a \& b) were consistent with the results obtained from studying the staining intensity and number of isoenzyme forms 
(Fig. $3 \& 4$ ). Increase the staining intensities of detected bands gave an indication about increase in the activity of the studied isoenzyme (Khavkin \& Zabtrodina 1994). Generally, the detected increase in SOD and POX activities due to salt stress or SA treatment was not because of expression of new isoenzyme form/s but duo to increase of the expression of the switched on isoloci.

Data of this work confirmed the participation of esterases in stress tolerant mechanisms as was previously reported by Hassanein (1999). In this concern, isoenzyme form number EST-4 was detected only under moderate and relatively high salt stress. In addition, its expression was detected under wide range of $\mathrm{NaCl}$ concentrations when plants were treated with SA more than salinizedSA-untreated plants. Esterases can liberate ferulic acid from polysaccharides which form components of lignin in plant cell wall (Scalbert et al. 1985; Faulds et al. 1998; Faulds et al. 2010). Dehydration stress was avoided when ferulic acid was used due to increase the activities of several antioxidant enzymes such as catalase, superoxide dismutase, and quaiacol peroxidase and it associated with increase transcripts of respective genes. Then, increase the activities of these enzymes decreased the contents of malondialdehyde, superoxide radical and hydrogen peroxide. To sustain stress tolerance, ferulic acid increased tissue water content and osmotic solutes such proline and soluble sugars resulting in growth improvement (Lee et al. 2013). Our data indicated that the role of esterase during salt stress may be partially due to sustain antioxidant system mediated by ferulic acid.

\section{REFERENCES}

Abdul Qados, A. (2015). Effects of salicylic acid on growth, yield and chemical contents of pepper (Capsicum annuum L) plants grown under salt stress conditions. International Journal of Agriculture and Crop Sciences, 8: 107-113. IJACS/2015/8-2/107-113
Faulds, C. B., (2010). What can feruloyl esterases do for us? Phytochemistry Reviews, 9: 121132 .

Mathew, S., and Abraham, T. E., (2004). Ferulic acid: an antioxidant found naturally in plant cell walls and feruloyl esterases involved in its release and their applications. Critical reviews in biotechnology, 24(2-3): 59-83.

Chakraborty, K, Bose, J, Shabala, L, Eyles, A, Shabala, S., (2016). Evaluating relative contribution of osmotolerance and tissue tolerance mechanisms toward salinity stress tolerance in three Brassica species. Physiologia Plantarum. 158(2): 135-51.

Faulds, C. B., Aliwan, F. O., De Vries, R. P., Pickersgill, R. W., Visser, J., \& Williamson, G. (1998). Chemical and thermal stability of ferulic acid (feruloyl) esterases from Aspergillus. Progress in Biotechnology 15: 41-46.

Acosta-Motos, J. R., Diaz-Vivancos, P., Álvarez, S., Fernández-García, N., Sánchez-Blanco, M. J. \& Hernánde J. A., (2015). NaClinduced physiological and biochemical adaptative mechanisms in the ornamental Myrtus communis L. Plants Journal of Plant Physiology, 183: 31-41. doi:10.1016/j.jplph.2015.05.005

Aebi, H., (1984). Catalase in vitro. Methods Enzymol, 105: 121-126. doi:10.1016/S0076-6879(84)05016-3

Bagheri, M.Z., (2014). The effect of maize priming on germination characteristics, catalase and peroxidase enzyme activity, and total protein content under salt stress. International Journal of Biosciences, 4(2): 104-112

Barkla B.J., Vera-Estrella R., (2015). Single celltype comparative metabolomics of epidermal bladder cells from the halophyte Mesembryanthemum crystallinum. Frontiers in Plant Science. 6: 435. doi: 10.3389/fpls..00435 
Beauchamp, C. and Fridovich, I., (1971). Superoxide dismutase: improved assays and an assay applicable to acrylamide gels. Analytical Biochemistry, 44: 276-287. PMID: 4943717

Brewer, G. J. (1970): An introduction to isoenzyme techniques. Academic Press, New York, San Francisco, London.

Davis, K., (2000). The Moringa Tree, (Revised edition). ECHO, 17391.Durrance Rd., North Ft. Myers FL 33917, USA. doi: 10.1016/j.jplph.2015.05.005

Demidchik, V., Cuin, T. A., Svistunenko, D., Smith, S. J., Miller, A. J., Shbala, S., Sokolik, A. and Yurin, V., (2010). Arabidopsis root $\mathrm{K}^{+}$-efflux conductance by hydroxyl radicals: single-channel properties, genetics basis and involvement in stress-induced cell death. Journal of Cell Science, 123: 1468-1479. doi: $10.1242 /$ jcs.064352.

El-Tayeb M. A., (2005). Response of barley grains to the interactive effect of salinity and salicylic acid. Plant Growth Regulation, 45: 215-224. doi:10.1007/s1007/s10725-005-4928-1.

Faheed, F. A., (2005). Effect of lead stress on the growth and metabolism of Eruca sativa M. seedling. Acta Agronomica Hungarica, 53: 319-327. doi: 10.1556/AAgr.53.2005.3.9

Faheed, F. A. (2012). Salicylic acid alleviates oxidative damage in sorghum plants grown under salinity and drought conditions. Assiut University Journal of Botany, 41: 225-251.

Faheed, F.A., Hassanein, A. M. and Azooz, M. M., (2005). Gradual increase in $\mathrm{NaCl}$ concentration overcomes inhibition of seed germination due to salinity stress in Sorghum bicolor (L.).Acta Agro Hung, 53: 229-239.

Fahey, J.W., Sc.D. (2005). Moringa oleifera: A review of the medical evidence for its nutritional, therapeutic, and prophylactic Properties. Part 1.

http://www.TFLJournal.org/article.php/20051 201124931586.

Gunes, A., Inal, A., Alpaslan, M., Eraslan, F., Bagci, E. G. and Cicek, N., (2007). Salicylic acid induced changes on some physiological parameters symptomatic for oxidative stress and mineral nutrition in maize (Zea mays L.) grown under salinity. Journal of Plant Physiology, 164: 728-736. doi:10.1016/j.jplph.2005.12.009.

Guo, Q., Liu, L., and Barkla, B. J., (2019). Membrane Lipid Remodeling in Response to Salinity. International journal of molecular sciences, 20(17): 4264. https://doi.org/10.3390/ijms20174264

Hassanein, A. M., (1999). Alternation in protein and esterase patterns of peanut plants in response to salinity stress. Biologia Plantarum, 42: 241- 248. doi:10.1023/A:100211270

Hayat, S., Hayat, Q., Alyemeni, M. N., Wani, A. S., Pichtel, J., and Ahmad, A., (2012). Role of proline under changing environments: a review. Plant signaling \& behavior, 7(11): 1456-1466. https://doi.org/10.4161/psb.21949

Hayat, Q., Hayat, S., Irfan, M. and Ahmad, A., (2010). Effect of exogenous salicylic acid under changing environment: a review. Environmental and Experimental Botany, 68: 14-25. doi:10.1016/j.envexpbot.2009.08.005.

Hernández, J. A. and Almansa, M. S. (2002). Short-term effects of salt stress on antioxidant systems and leaf water relations of pea plants. Physiologia Plantarum, 115: 251-257. doi:10.1034/j.1399-354.2002.1150211.x.

Hewitt, E. J., (1963). Nutrition of plants in culture media. In: Steward FC. Plant 
Physiology, Vol 111. Academic Press, New York. Pp. 97-133.

Horvath, E., Pal, M., Szalai, E. and Janda, T., (2007). Exogenous 4-hydroxybenzoic acid and salicylic acid modulate the effect of short-term drought and freezing stress on wheat plants. Biologia Plantarum, 51: 480487. doi:10.1007/s10535-007-0101-1.

Huang, Y., Chen, C., Chen, W. L., Ciou, Y., Yang, T. and Yang, C., (2013). Production and antioxidant properties of the ferulic acid rich destrached wheat bran hydrolysate by feruloyl esterases from thermophilic Actinomycetes. Bioresources 8: 4981-4991. doi.10.15376/biores.8.4.4981-4991.

Jini D. and Joseph, B., (2017). Salicylic acid mediated salt tolerance at different growth stages of Oryza sativa L. and its effect on salicylic acid biosynthetic pathway genes. Biotechnol Ind J 13(2):134.

Kazemi, M., Hadavi, E. and Hekmati, J., (2011). Role of salicylic acid in decreases of membrane senescence in cut carnation flowers. American Journal of Plant Physiology, 6: 106-112. doi:10.3923/ajpp.2011.106.112.

Khavkin, E. E, and Zabrodina, M. V., (1994). Heritable variation in peroxidase and esterase isoenzyme patterns of maize somaclone. Fiziol Rast, 14: 754-761.

Knorzer, O. C., Lederer, B., Durner, J. \& Boger, P. (1999). Antioxidative defense activation in soybean cells. Physiologia Plantarum, 107: 294-302. doi:10.1034/j.1399-3054.1999.100306.x.

Love, A. J., Milner, J. J. and Sadanandom, A. (2008). Timing is everything: regulatory overlap in plant cell death. Trends Plant Sci. 13: 589-595. doi: 10.1016/j.tplants.2008.08.006.
Lee, Y. P., Ahmad, R., Lee, H. S., Kwak, S. S., Shafqat, M. N. and Kwon, S. Y., (2013). Improved tolerance of $\mathrm{Cu} / \mathrm{Zn}$ superoxide dismutase and ascorbate peroxidase expressing transgenic tobacco seeds and seedlings against multiple abiotic stresses. International Journal of Agriculture and Biolology, 15: 725-730.

http://www.fspublisher.org. 12-624/2013/154-725-730.

Lichtenthaler, H. K., (1987). Chlorophylls and carotenoids: pigments of photosynthetic biomemranes. Methods in Enzymology, 148: 350-382. doi:10.1016/0076-6879(87)48036-1

Liu, S., Dong, Y., Xu, L. and Kong, J., (2014). Effects of foliar applications of nitric oxide and salicylic acid on salt-induced changes in photosynthesis and antioxidative metabolism of cotton seedlings, Plant Growth Regulation, 73: 67-78.

Ma, X., Zheng, J., Zhang, X., Hu, Q. and Qian, R., (2017). Salicylic acid alleviates the adverse effects of salt stress on Dianthus superbus (caryophyllaceae) by activating photosynthesis, protecting morphological structure, and enhancing the antioxidant system. Front Plant Sci., 8, 600. doi:10.3389/fpls.2017.00600

MacAdams, J. W., Nelson, C. J. and Sharp R. E. (1992). Peroxidase activity in the leaf elongation zone of tall fescue. Plant Physiology, 99, 872-878. 00320889/92/99/0872/07/S01.00/0

Mittler, R., (2002). Oxidative stress, antioxidants, and stress tolerance. Trends Plant Sci., 7:405410. doi:10.1016/S1360-1385(02)02312-9

Miyake, C. and Asada, K. (1994). Ferredoxindependent photo reduction of the monodehydro ascorbate radical in spinach thylakoids. Plant Cell Physiology, 35: 539549. 
Nakano, Y. and Asada, K., (1981). Hydrogen peroxide is scavenged by ascorbate-specific peroxidase in spinach chloroplasts. Plant Cell Physiology, 22: 867-88.

Panda, S. K. and Patra, H. K., (2007). Effect of salicylic acid potentiates cadmium-induced oxidative damage in Oriza sativa L. leaves. Acta Physiologiae Plantarum, 29: 567-577. doi:10.1007/s11738-007-0069-7.

Pirasteh-Anosheh, H., Ranjbar, G., Emam, Y. and Ashraf, M., (2014). Salicylicacid-induced recovery ability in salt-stressed Hordeum vulgare plants. Turkish Journal of Botany, 38: 112-121. doi:10.3906/Bot-1302-20.

Poór, P., Szopkó, D. and Tari, I., (2011b). Ionic homeostasis disturbance is involved in tomato cell death induced by $\mathrm{NaCl}$ and salicylic acid. In Vitro Cell Dev Biol Plant., 48: 377-382. doi:10.1007/s11627-011-94197.

Qadir, M., Quillérou, E., Nangia, V., Murtaza, G., Singh, M., Thomas, R. J. \& Noble, A. D. (2014). Economics of salt-induced land degradation and restoration. Natural resources forum, 38: 282-295.

doi: $10.1111 / 1477-8947.12054$.

Quan, L. J., Zhang, B., Shi, W. W. \& Li, H. Y. (2008). Hydrogen peroxide in plants: a versatile molecule of the reactive oxygen species network. J Integr Plant Biol., 50: 218. doi:10.1111/j.1744-7909.2007.00599.x.

Ramel, F., Birtic, S., Cuiné, S., Triantaphylidès, C., Ravanat, J. L., and Havaux, M. (2012). Chemical quenching of singlet oxygen by carotenoids in plants. Plant Physiology, 158: 1267-1278. doi:10.1104/pp.111.182394.

Scalbert, A., Monties, B., Lallemand, J. Y., Guittet, E. and Rolando, C., (1985). Ether linkage between phenolic acids and lignin fractions from wheat straw. Phytochemistry, 24: $1359-1362$. doi:10.1016/S0031-9422(00)81133-4.
Senaratna, T., Touchell, D., Bunn, E. and Dixon, K., (2000). Acetyl salicylic acid and salicylic acid induce multiple stress tolerance in bean and tomato plants. Plant Growth Regulation, 30: 157-161. doi: 10.1023/A:1006386800974.

Sharma, M. and Laxmi, A., (2015). Jasmonates: Emerging players in controlling temperature stress tolerance. Frontiers in Plant Science, 6, 1129. doi: 10.3389/fpls.2015.01129.

Shobbar, M. S., Niknam, V., Shobbar, Z. S. and Ebrahimzadeh, H., (2010). Effect of salt and drought stresses on some physiological traits of three rice genotypes differing in salt tolerance. JUST 36 (2):1-9.

Siegel, B. Z. and Galston, A. W., (1967). The isoperoxidases of Pisum sativum. Plant Physiology, 42: 221-226. doi:10.1104/pp.42.2.221

Torabi, F., Majd, A. \& Enteshari, S. (2015). The effect of silicon on alleviation of salt stress in borage (Borago officinalis L.). Journal of Soil Science and Plant Nutrition, 61: 788798. doi: 10.1080/00380768.2015.100554

Tripathi, D. K., Singh, S., Singh, V. P., Prasad, S. M., Dubey, N. K. and Chauhan, D. K. (2017). Silicon nanoparticles more effectively alleviated UV-B stress than silicon in wheat (Triticum aestivum) seedlings. Plant Physiology and Biochemistry, 110: 70-81. doi: 10.1016/J.Plaphy.2016. 06.026

Javaheri M., Mashayekhi K., Dadkhah A., Tavallaee F.Z., (2012). Effects of salicylic acid on yield and quality characters of tomato fruit (Lycopersicum esculentum Mill.). International journal of agriculture and crop sciences, 4 (16): 1184-1187

Yan, B., Dai, Q., Liu, X., Huang, S. and Wang, Z., (1996). Flooding-induced membrane damage, lipid oxidation and activated oxygen generation in corn leaves. Plant Soil, 179: 261-8. 
Yang, Y. L., Zhang, F., He, W. L., Wang, X. M. and Zhang L. X., (2003). Iron-mediated inhibition of $\mathrm{h}+$-ATPase in plasma membrane vesicles isolated from wheat roots. Cell Mol Life Sci., 60: 1249-1257

Wu, H., Zhang, X., Giraldo, J. P. and Shabala S., (2018). It is not all about sodium: revealing tissue specificity and signalling roles of potassium in plant responses to salt stress. Plant Soil 431: 1-17. https://doi.org/10.1007/s11104-018-3770-y
Zhang, X. Z., (1992). Research methodology of crop physiology. Agricultural Press, Bijing, 208-211.

Zhang, L. X., La, Z. S. and Ashraf, M., (2014). Interactive effects of sudden and gradual drought stress and foliar-applied glycinebetaine on growth, water relations, osmolyte accumulation and antioxidant defence system in two maize cultivars differing in drought tolerance. Journal of Agronomy and Crop Science, 200, 425-433. doi:10.1111/jac.12081 